\title{
ORIENTAÇÃO ESTÉTICA E SOCIEDADE: uma conexão a explorar
}

\section{Bruno Moretti*}

CANDIDO, Antonio. Literatura e sociedade. Rio de Janeiro: Ouro sobre Azul, 2006. 202 p.

Em 2006, foi relançado o livro Literatura e sociedade, de Antonio Candido, publicado originalmente em 1965, sendo de fundamental interesse a qualquer estudioso da literatura brasileira.

A relação entre literatura e sociedade é o tema do qual resulta a unidade do conjunto de ensaios que compõem o livro, dividido em duas partes: a primeira procura, de um ponto de vista geral, estabelecer os pressupostos da investigação da relação entre a obra de arte (especialmente, a literatura) e os fatores sociais; a outra lida com esta mesma relação, remetendo, entretanto, sob vários aspectos, à experiência social brasileira.

Vale tecer breves comentários sobre as duas partes, iniciandose pela primeira. Neste caso, há conclusões fundamentais a estudiosos da crítica literária (ou simplesmente crítica, como prefere o autor) e da Sociologia da Literatura. A tese mais profícua se refere à irredutibilidade da obra a seus condicionamentos externos, questão ainda hoje tão debatida na Sociologia. Candido aborda o tema, na verdade, de modo a superar a dicotomia entre uma leitura externa (que exaure a obra nos seus condicionamentos sociais) e uma leitura

* Doutorando do Programa de Pós-Graduação de Sociologia da Universidade de Brasília (UnB). 
interna (esta, por sua vez, autonomiza o texto, salientando o gênio criativo do autor).

A abordagem de Candido toma a obra como uma estrutura orgânica (sem qualquer concessão a uma posição próxima ao estruturalismo), articulada por um conjunto de fatores. Apenas na fatura de cada obra (e, por conseguinte, analisada em si própria, como objeto singular) é que se poderia investigar o relacionamento dinâmico entre estes. Do ponto de vista da crítica, interessaria desnudar este vínculo, a partir do qual já não tem primazia a natureza de cada fator (social, psicológico etc.), uma vez que todos eles se transformam em elementos estéticos, combinando-se. Em outros termos, a superação das leituras externa e interna é viabilizada pela categoria da transfiguração, por intermédio da qual fatores externos se convertem em internos; movimento que consiste de estilização formal, executada pelo escritor, segundo sua própria mônada, "recriando", "reconstruindo" o mundo a seu modo. Assim, o trabalho literário sempre impõe um sentido próprio, imaginário, à realidade, não se assemelhando, por conseguinte, à reprodução mecânica de evidências, fatos e instituições da ordem social. Entre mundo e obra, há um sujeito ativo (sua visão de mundo, psique, intenções, recursos etc.), combinando, de modo mais ou menos feliz, dados que passam a ser - indistintamente - elementos da estrutura.

Contudo, salienta o autor, a obra também não emerge num vazio de determinações sociais, uma vez concebida a literatura (a rigor, qualquer arte) como um sistema simbólico de comunicação social e no qual, por essa razão, estão implicados autor, obra e público. Se esse é o caso, a literatura é atividade coletiva, pressupondo códigos compartilhados entre agentes (academias de letras, escritores, público etc.), relativos a estilos, gostos, valores, temas, técnicas de comunicação e outros.

É sob esta perspectiva, à qual se poderia denominar dialética, que em "Crítica e Sociologia", Antonio Candido investiga o papel 
da crítica, detida nas considerações sobre a economia da obra, particularmente em sua composição a partir de elementos que passam a ser a ela internos, enquanto a Sociologia se preocuparia tão-somente com o trato externo dos condicionamentos externos. Aqui, contudo, vale uma ressalva: tal divisão do trabalho entre disciplinas parece excessivamente rígida, retirando da Sociologia da Literatura, por exemplo, o papel de tomar a obra como objeto no qual deságua, por meio do trabalho de formalização sobre a linguagem, uma estrutura social particular. Parece que tal rigidez é contraditória com a própria concepção do autor, visto que a transfiguração do social em estético mandaria relativizar um compartilhamento de tarefas entre departamentos baseada na ênfase no elemento externo ou interno, já que um se converte no outro, flexibilizando definições sobre sua posição com relação à obra.

Já em "A Literatura e a Vida Social", Candido procura explicitar alguns fatores sociais que condicionam a vida literária (sem jamais explicá-la), ligados, ao menos os mais relevantes, à estrutura social, valores e ideologias e às técnicas de comunicação. Em "Estímulos da Criação Literária", o autor lida com as diferenças entre a vida literária em sociedades "primitivas" e "civilizadas".

Passa-se agora ao segundo grupo, mais propriamente histórico. Em “O Escritor e o Público”, Candido estuda as condições de produção da literatura no Brasil, especialmente, a relação entre escritor e público, que assume uma posição social mutável ao longo da nossa história; relação que envolve muitos aspectos, como o grau de desenvolvimento da indústria editorial, mas também as ligações entre escritor e grupos dirigentes.

"Letras e Idéias no Período Colonial" coloca a questão da formação de uma tradição literária no Brasil. Sob esta perspectiva, pode observar, ao longo da vida colonial, a existência de duas vertentes literárias. A primeira expressa vínculos frágeis entre as 
diversas manifestações literárias. Vige do século XVII ao XVIII, estando ligada à literatura portuguesa e à justificação ideológica da colonização, incorporando elementos religiosos e de transfiguração das letras da metrópole para a colônia. A outra, sucedânea da visão transfiguradora, caracteriza-se pela influência do Iluminismo, em virtude da qual penetram em nossa literatura elementos como a confiança na razão e no progresso, associados à captura de um real particular, donde se extrai o nativismo, o nacionalismo e a defesa da independência política. É este o momento em que se inicia (e do qual resulta) a composição de um sistema literário orgânico e articulado no Brasil.

"Literatura e Cultura de 1900 a 1945" se concentra na dialética entre localismo e cosmopolitismo, princípio estruturante da constituição e desenvolvimento de nossas letras. O autor explicita momentos fundamentais deste processo, como, por exemplo, a gênese do Modernismo. Ademais, trata da evolução de uma espécie de divisão intelectual do trabalho entre literatura e outras esferas do pensamento social no Brasil.

O ensaio "A Literatura na Evolução de uma Comunidade" traça diferentes formas históricas de associação entre escritores na cidade de São Paulo, bem como as normas e valores que os orientaram, buscando assinalar qual a sua relação com o movimento da sociedade como um todo.

Por último, "Estrutura Literária e Função Histórica" toma como objeto uma obra específica - Caramuru -, do Frei José de Santa Rita Durão, escrita em 1781. Candido defende a hipótese de que, meio século após sua publicação, a obra teve função primordial para a formação de uma consciência literária autônoma, que emerge junto com o Romantismo e sua ênfase na brasilidade. A causa deste fenômeno, o autor vai buscar na própria fatura do texto, na forma 
com que organiza os elementos que a compõem, que permitiria fazê-lo cumprir as funções requeridas, ainda que em um outro momento histórico. O ensaio expressa, novamente, o vínculo que o autor procura construir entre fatores histórico-sociais e orientação estética.

Enfim, Literatura e sociedade é ainda hoje obra fundamental, a despeito dos mais de 40 anos de sua primeira publicação. Em especial, aos sociólogos que se interessam pelo tema, há conclusões importantes acerca da natureza do fenômeno estético. Candido apresenta uma concepção que parece resguardar a peculiaridade do texto literário, mas também aponta para sua articulação, em graus distintos, com fatores sociais. Ademais, ao operacionalizar - nesta e em outras obras - sua abordagem, adianta interpretações fundamentais à compreensão do movimento histórico do mundo das idéias no Brasil. De modo que não constituiria qualquer exagero situar os escritos de Antonio Candido (ainda que detidos em um ângulo específico - o literário) entre os clássicos brasileiros, que tematizaram nossa formação nacional, como, por exemplo, Raízes do Brasil, de Sérgio Buarque de Holanda, Casa Grande e Senzala, de Gilberto Freyre, e Formação do Brasil Contemporâneo, de Caio Prado Junior. 